\title{
Calcareous nannofossil and foraminifer biostratigraphy of the Campanian-Maastrichtian chalk of the Femern Bælt (Denmark-Germany)
}

\author{
Emma Sheldon, Caterina Morigi and Sarah D. Møller
}

A new study based on calcareous nannofossil and benthic and planktonic foraminifer biostratigraphy is presented for the upper Campanian - Maastrichtian chalk of the Femern Bælt (Denmark and Germany; Fig.1). The results are consistent with recent studies of the Danish chalk for this interval, allowing correlation across the Danish Basin and forming the basis for correlation further afield within the Boreal Realm. Numerous studies have been carried out recently on the upper Campanian - Maastrichtian chalk of the Danish Basin, covering aspects such as sedimentology, depositional environment, macrofossil biostratigraphy, carbon isotope stratigraphy as well as nannofossil and dinoflagellate biostratigraphy. However, very few published studies on foraminifers exist across this interval in this area. The 09.A.006, 09.A.007 and 09.A.008 boreholes (Fig. 2) were drilled in 2009 in preparation for construction of a fixed link across the Femern Bælt, which will connect Denmark to Germany (Rambøll Arup JV 2011). The boreholes penetrated glacial till, Paleocene-Eocene clay and chalk (Sheldon et al. 2012). Here, for the first time, the Boreal foraminifer biostratigraphy of the late Campanian - Maastrichtian interval is investigated and presented alongside nannofossil biostratigraphy.

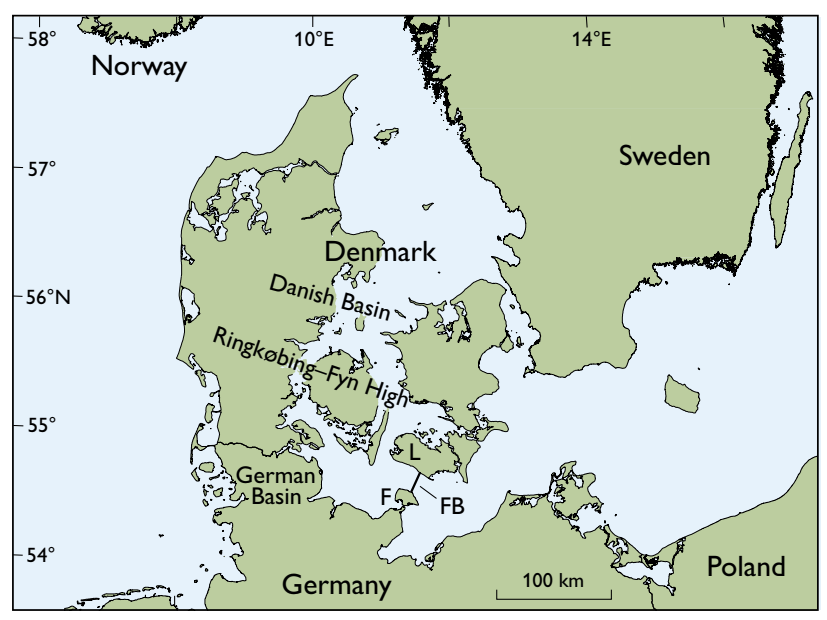

Fig.1. Map of Denmark and northern Germany showing the location of the planned fixed road and rail link across Femern Bælt. L: Lolland, F: Fehmarn, FB: Femern Bælt.

\section{Geological setting and palaeogeography}

The Femern Bælt area is located to the south of the Ringkøbing-Fyn High and is part of the German Basin (Fig. 1). During the Late Cretaceous the Danish area was part of the extensive epicontinental sea where cool-water carbonate deposition dominated. The Maastrichtian chalk was deposited at depths of 100-250 m (Surlyk 1997). Chalk distribution patterns are affected in the Danish area by folding, salt diapirism, non-deposition and erosion, especially in the southern region (Lieberkind et al. 1982). In the Maastrichtian to Danian, the area was situated at $44^{\circ}-46^{\circ} \mathrm{N}$ (Smith et al. 1994). In the upper Maastrichtian of this part of the Danish area, two main facies types dominate: (1) relatively deep water basinal sediments comprising coccolith and foraminferarich pelagic chalk, and (2) shallow marine chalk with high diversity faunas dominated by bryozoans, echinoids, bivalves and brachiopods (Surlyk 1997; Hart et al. 2004).

The upper Campanian - Maastrichtian chalk of onshore Denmark was until recently referred to the Tor Formation equivalent. The Tor Formation was established by Deegan \& Scull (1977) as a Maastrichtian (locally upper Campanian) chalk unit in the Norwegian and Danish sectors of the North Sea. A new holostratigraphic analysis of the upper Cretaceous chalk of eastern Denmark resulted in a lithostratigraphic subdivision of the onshore chalk (Surlyk et al. 2013). However due to local facies variations this new subdivision cannot be applied to the chalk of the Femern Belt area with-

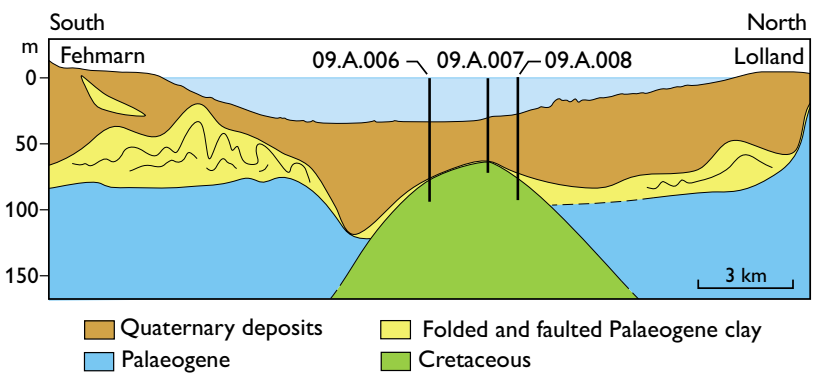

Fig. 2. Sketch south-north cross-section of the Femern Bælt area and the location of the boreholes (from Sheldon et al. 2012). 
out sedimentological analysis and the term 'Tor Formation equivalent' is retained here.

\section{Biostratigraphy}

From the 09.A.008 and 09.A.006 boreholes nannofossils and foraminifers from the Campanian-Maastrichtian were analysed; from the 09.A.007 borehole nannofossils from the upper Maastrichtian were examined. The southern North Sea foraminifer zonation of King et al. (1989) and the Boreal nannofossil scheme of Burnett (1998) were applied (Fig. 3). Marker species are shown in Fig. 4 and biostratigraphic results on Fig. 5.

Nannofossilzones - The co-occurrence of Orastrum campanensis and Eiffelithus eximius indicates the presence of $\mathrm{UC} 15 \mathrm{~d}^{\mathrm{BP}}$ at the base of core 09.A.008. Subzone UC15e $\mathrm{B}^{\mathrm{BP}}$ is absent. UC16 ${ }^{\mathrm{BP}}$ was defined by Burnett (1998) but recent studies of Danish Campanian-Maastrichtian chalks (Sheldon 2008; Thibault et al. 2012) question the reliability of the $\mathrm{UC} 16^{\mathrm{BP}}$ marker species in the Danish area. The top of $\mathrm{UC16a}{ }^{\mathrm{BP}}$ is defined by the last occurrence (LO) of Heteromarginatus bugensis. In the present study and in the Stevns-1 borehole, eastern Denmark, the LO of H. bugensis is below the LO of Tortolithus caistorensis

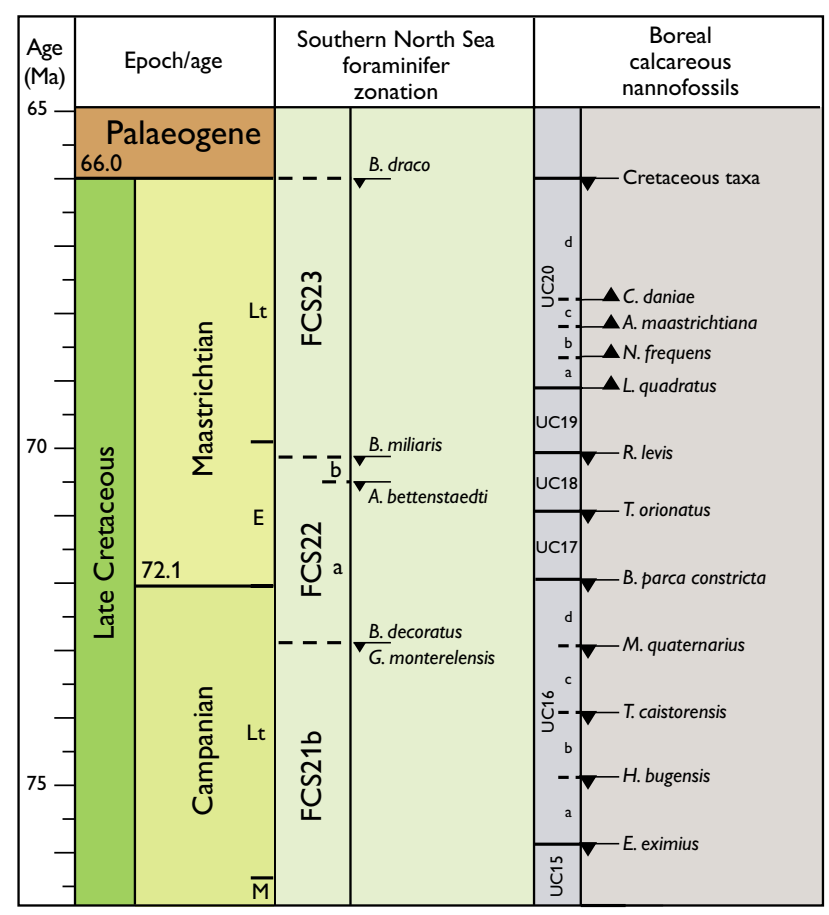

Fig. 3. Nannofossil and foraminifer zonations. The timescale is according to Gradstein et al. (2012). UC ${ }^{\mathrm{BP}}$ : Upper Cretaceous Boreal Province nannofossil zones of Burnett (1998), FCS: Cretaceous southern North Sea Foraminfers, shelf facies, including chalk, zones of King et al. (1989). Nannofossil and foraminifer zonations correlated using Fritsen (1999). (marker for top UC16b ${ }^{\mathrm{BP}}$ ). Other studies (e.g. Fritsen et al. 1999) assign the LO of H. bugensis to the top of $\mathrm{UC} 16 \mathrm{c}^{\mathrm{BP}}$. The top of $\mathrm{UC} 16 \mathrm{~b}^{\mathrm{BP}}$ is defined by the $\mathrm{LO}$ of $T$. caistorensis, which is very rare in the Danish area. $\mathrm{UC16} \mathrm{a}^{\mathrm{BP}}$ and $\mathrm{b}$ are not easily subdivided in the Danish area and alternative markers are suggested for the top of $\mathrm{UC} 16 \mathrm{~b}^{\mathrm{BP}}$ : the LO's of Tortolithus hallii and Tortolithus pagei were successfully applied in the present study, positioned prior to the LOs of Broinsonia parca parca and Zeugrhabdotus praesigmoides (markers for the overlying $\left.\mathrm{UC1} 16 c^{\mathrm{BP}}\right)$. The top of $\mathrm{UC1} 16 \mathrm{c}^{\mathrm{BP}}$ is defined by the LO of Monomarginatus quaternarius. The LO of $B$. parca parca as a top $\mathrm{UC1} 16 \mathrm{c}^{\mathrm{BP}}$ marker is a more reliable marker in this study. The $\mathrm{LO}$ of $Z$. praesigmoides as an additional top $\mathrm{UC} 16 \mathrm{c}^{\mathrm{BP}}$ marker is confirmed in this study. The top of subzone $\mathrm{UC} 16 \mathrm{~d}^{\mathrm{BP}}$ is defined by the LO of Broinsonia parca constricta. The first occurrence (FO) of Prediscosphaera mgayae as an additional marker

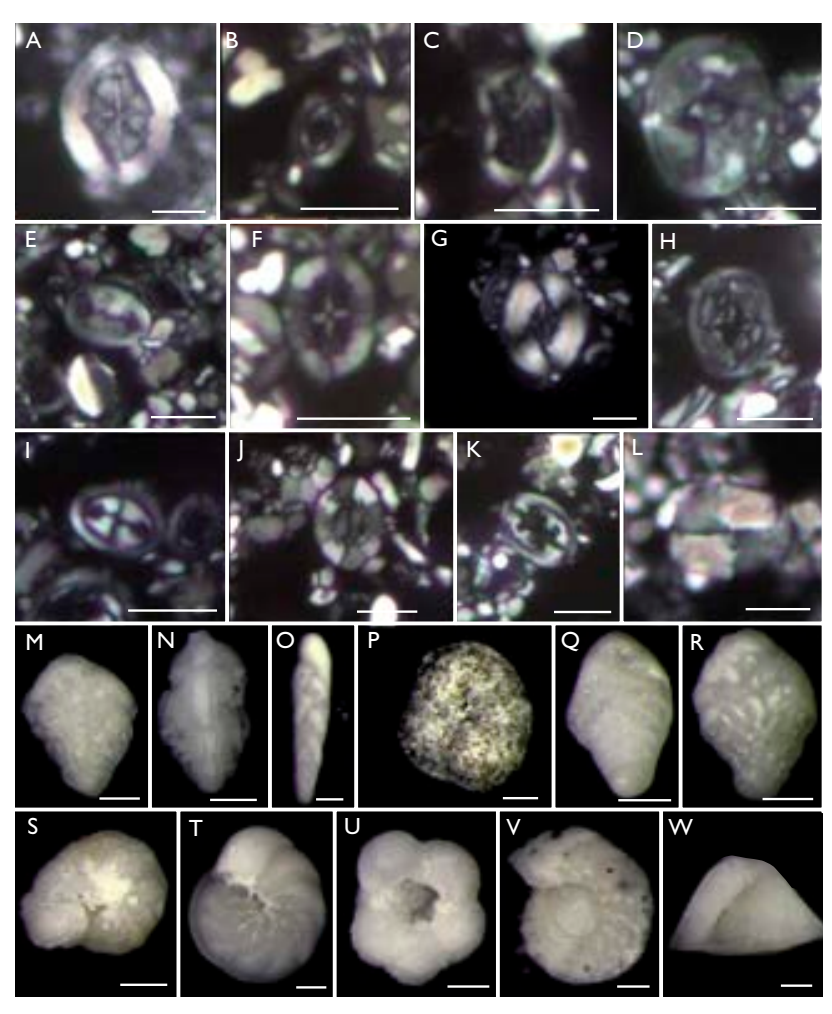

Fig. 4. Sselected nannofossils and foraminifers from the Femern Bælt. A: Arkhangelskiella maastrichtiana. B: Prediscosphaera stoveri. C: Nephrolithus frequens. D: Reinhardtites levis. E: Tranolithus orionatus. F: Prediscosphaera mgayae. G: Broinsonia parca constricta. H: Monomarginatus quaternarius. I: Zeugrhabdotus praesigmoides. J: Tortolithus caistorensis. K: Heteromarginatus bugensis. L: Orastrum campanensis. M: Bolivinoides draco. N: Pseudouvigerina cristata. O: Brizalina incrassata. P: Hagenowella paleocenica. Q: Bolivinoides draco giganteus. R: Bolivinoides decoratus. S: Stensioeina pommerana. T: Angulogavelinella bettenstaedti. U: Globotruncana arca. V: Gavelinella monterelensis. W: Globorotalites micheliana. Scale bars, nannofossils: $5 \mu \mathrm{m}$, foraminifers: $0.1 \mathrm{~mm}$. 

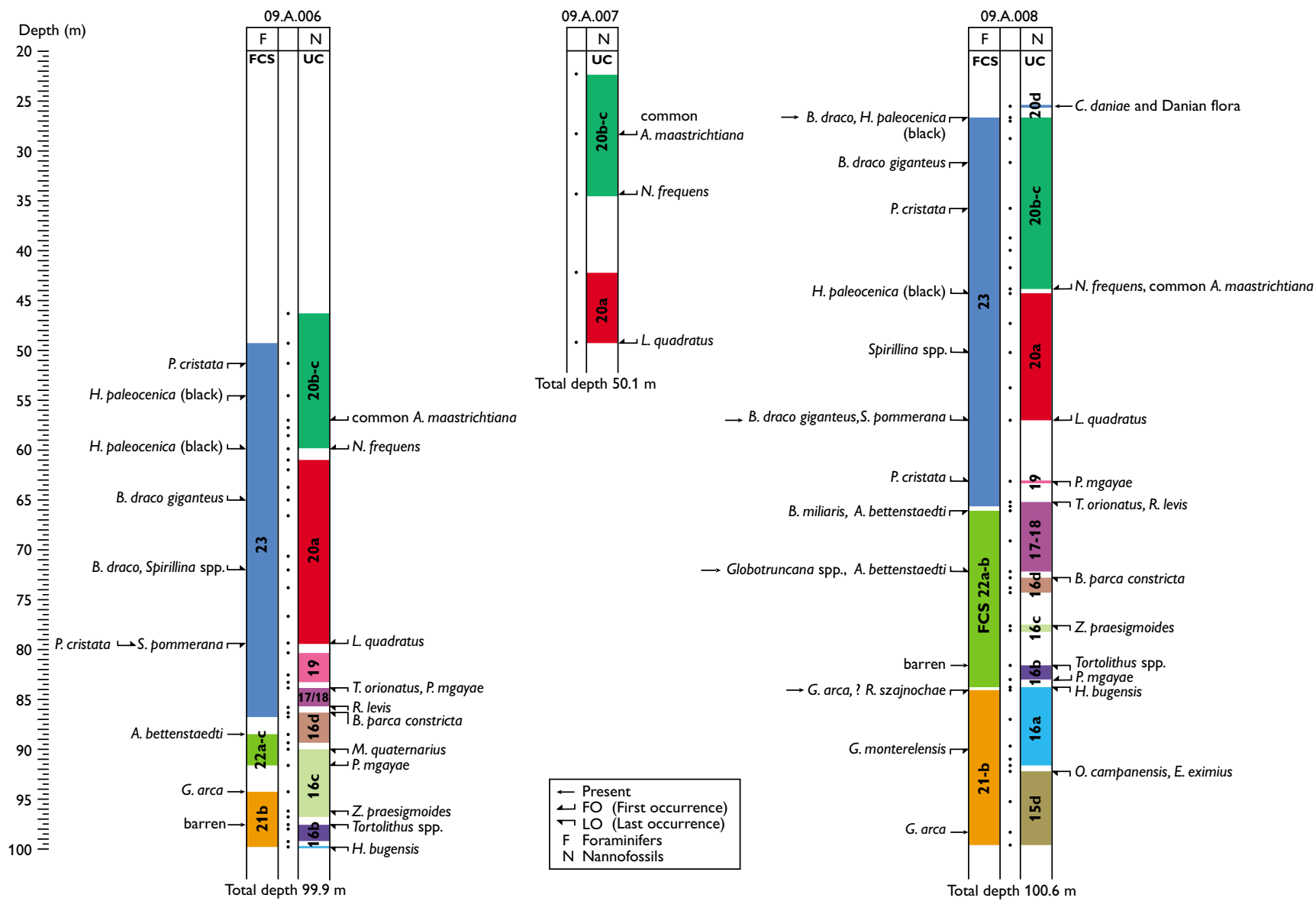

Fig. 5. Nannofossil and foraminifer biostratigraphic correlations of the three boreholes at the Femern Bælt.

in the middle of UC16d ${ }^{\text {BP }}$ (Thibaut et al. 2012) is confirmed in this study. The LO of Tranolithus orionatus marks the top of $\mathrm{UC} 17^{\mathrm{BP}}$. In the present study, the LO of this species occurred after the LO of Reinhardtites levis (the LO of which marks the top of the overlying $\mathrm{UC} 18^{\mathrm{BP}}$ ). In Stevns-1 these species also occur in the 'reverse' order. The LO of R. levis marks the top of $\mathrm{UC} 18^{\mathrm{BP}}$, but in this study its $\mathrm{LO}$ is before that of $T$. orionatus. It is suggested that in the Danish area, $\mathrm{UC} 7^{\mathrm{BP}}$ and $\mathrm{UC} 18^{\mathrm{BP}}$ should be combined, using either the $\mathrm{LO}$ of T. orionatus or the LO of $R$. levis to mark the zone top. The LO of $P$. mgayae has been suggested as an additional marker for the top of this zone (Thibaut et al. 2012); this is confirmed in this study. UC19 ${ }^{\mathrm{BP}}$ comprises the interval from the LO of Reinhardtites levis to the FO of Lithraphidites quadratus. The FO of $L$. quadratus defines the base of $\mathrm{UC} 20 \mathrm{a}^{\mathrm{BP}}$. The base of $\mathrm{UC} 20 \mathrm{~b}^{\mathrm{BP}}$ is defined by the FO of Nephrolithus frequens. The base of $\mathrm{UC}^{20} \mathrm{c}^{\mathrm{BP}}$ is defined by the $\mathrm{FO}$ of Arkhangelskiella maastrichtiana. The uncertainties surrounding the use of the $\mathrm{FO}$ of $A$. maastrichtiana as a marker are well-documented (e.g. Thibault 2010) and the two subzones are merged here. The first common occurrence of $A$. maastrichtiana is used to mark the base of $\mathrm{UC} 20 \mathrm{~b}-\mathrm{c}^{\mathrm{BP}}$ in this study. The base of the Prediscosphaera stoveri acme within this combined subzone is also applied successfully in this study. The LO of Helicolithus trabeculatus was suggested as a supplementary marker for this level (Sheldon 2008) and is confirmed here. The FO of Cribrosphaerella daniae marks the base of $\mathrm{UC} 20 \mathrm{~d}^{\mathrm{BP}}$, the uppermost subzone of the Maastrichtian. The co-occurrence of Chiasmolithus edentulus, Coccolithus pelagicus, Cyclagelosphaera alta and Neochiastozygus saepes assigns the base of the overlying Danian in borehole 09.A.008 to the upper Danian subzone NNTp4F (Varol 1998). Lower - upper Danian subzones NNTp1A-4F are missing or were not sampled. Danian chalk in the Femern area was documented for the first time recently (Sheldon et al. 2012). Previously the southern limits of Danian deposits were thought to be farther to the north (Håkansson \& Pedersen 1992).

Foraminifer zones - The top of FCS23 is defined by the LO of Pseudotextularia elegans. Bolivinoides draco (s.s.) is an index species. The top of subzone FCS23a is defined by the FO of P. elegans. P. elegans is not seen in the present study, but rare occurrences of Bolivinoides draco were noted, indicating the 
presence of FCS23. In upper FCS23 the range of Hagenowella paleocenica and the FO of Spirillina spp. are additional markers in the present study. The LO of Stensioeina pommerana occurring towards the bottom of FCS23 (corresponding to the base of nannofossil subzone $\mathrm{UC} 20 \mathrm{a}^{\mathrm{BP}}$ ) in this study may also prove useful. The range of Pseudouvigernina cristata within FCS23 may prove to be another useful marker. The absence of $P$. elegans means that it is not possible to subdivide FCS23 in this study. The top of FCS22 is defined by the LO of Bolivinoides miliaris. FCS22 is divided into FCS22b, the top of which is defined by the LO of B. miliaris, and FCS22a, the top of which is defined by the LO of Angulogavelinella bettenstaedti. The LOs of $A$. bettenstaedti and B. miliaris occurred in the same sample suggesting the presence of only FCS22a, but the range of $A$. bettenstaedti within FCS22 could be useful. The top of FCS21 is defined by the LO (often a flood occurrence) of Reussella szajnochae. FCS21 is divided into FCS21b, the top of which is defined by the LO of $R$. szajnochae, and FCS21a, the top of which is defined by the LO of Gavelinella usakensis. G. usakensis was not found in the present study, indicating the presence only of FCS21b. The LO of Globotruncana arca at the top of FCS21 is an additional marker, as are the LOs of Gavelinella monterelensis and Globorotalites micheliana and FO of Brizalina incrassata at a slightly lower stratigraphic level.

\section{Conclusions}

The Campanian-Maastrichtian chalk of the Danish area has recently been studied intensively using calcareous nannofossils, applying the $\mathrm{UC}^{\mathrm{BP}}$ scheme. The studies underline the need for an amendment of the UC scheme for the Danish area. The present study highlights the need to reconsider the subdivision of $\mathrm{UC} 20 \mathrm{~b}^{\mathrm{BP}}$ and $\mathrm{UC} 20 \mathrm{c}^{\mathrm{BP}}$ based on the FO of Arkhangelskiella maastrichtiana. It is recommended for the Danish area to use the $\mathrm{FO}$ of common $A$. maastrichtiana to mark the base of $\mathrm{UC} 20 \mathrm{C}^{\mathrm{BP}}$. It may also be practical to merge $\mathrm{UC} 17^{\mathrm{BP}}$ and $\mathrm{UC} 18^{\mathrm{BP}}$. Additionally the subdivision of $\mathrm{UC} 16^{\mathrm{BP}}$ cannot be reliably applied in the Danish area. The Danian nannofossil assemblage in borehole 09.A.008 provides further evidence for the southerly encroachment of the Danian sea.

The foraminifer zonation of the Late Campanian - Maastrichtian is for the first time correlated with the nannofossil zonation based on the 09.A.006 and 09.A.008 cores (Fig. 5). In the absence of certain established FCS marker foraminifera for the North Sea chalk, new zonal markers, e.g. Hagenowella paleocenica, Pseudouvigerina cristata, Globotruncana arca, Gavelinella monterelensis and Globorotalites micheliana are used here in addition to conventional taxa for the Campanian-Maastrichtian chalk of Denmark, perhaps allowing correlation with the North Sea area, and further afield.

\section{References}

Burnett, J.A. 1998: Upper Cretaceous. In: Bown, P.R. (ed.): Calcareous nannofossil biostratigraphy. British Micropalaeontological Society Series 5, 132-199.

Deegan, C.E. \& Scull, B.J. 1977: A standard lithostratigraphical nomenclature for the central and northern North Sea. The Institute of Geological Sciences Report 77/25, 36 pp.

Fritsen, A. (ed.) 1999: A joint chalk stratigraphic framework. In: Joint chalk research program topic V 1. Norwegian Petroleum Directorate. 206 pp.

Gradstein, F.M., Ogg, J.G., Schmitz, M.D. \& Ogg, G.M. 2012: The geologic time scale 2012, 1176 pp. Amsterdam: Elsevier.

Hart, M.B., Feist, S.E., Price, G.D. \& Leng, M.J. 2004: Reappraisal of the K-T boundary succession at Stevns Klint, Denmark. Journal of the Geological Society (London) 161, 885-892.

Håkansson, E., \& Pedersen, S.A.S. 1992: Geologisk kort over den danske undergrund. Map sheet. København: Varv.

King, C., Bailey, H.W., Burton, C.A. \& King, A.D. 1989: Cretaceous of the North Sea. In: Jenkins, D.G. \& Murray, J.W. (eds): Stratigraphic atlas of fossil foraminifera, 372-417. Chichester: Ellis Horwood.

Lieberkind, K., Bang, I., Mikkelsen, N. \& Nygaard, E. 1982: Late Cretaceous and Danian limestone. Danmarks Geologiske Undersøgelse Serie B 8, 49-62.

Rambøll Arup JV 2011: Summary of geological conditions. Geotechnical Data Report 01.3-002, 53 pp. Virum: Femern A/S.

Sheldon, E. 2008: Upper Campanian-Maastrichtian calcareous nannofossil biostratigraphy of the Stevns-1 borehole, Denmark. Journal of Nannoplankton Research 30, 39-49.

Sheldon, E., Gravesen, P. \& Nøhr-Hansen, H. 2012: Geology of the Femern Bælt area between Denmark and Germany. Geological Survey of Denmark and Greenland Bulletin 26, 13-16.

Smith A.G., Smith, D.G. \& Funnel, B.M. 1994: Atlas of Mesozoic and Cenozoic coastlines, 99 pp. Cambridge: Cambridge University Press.

Surlyk, F. 1997: A cool-water carbonate ramp with bryozoan mounds: Late Cretaceous - Danian of the Danish Basin. SEPM Special Publication 56, 293-307.

Surlyk, F., Rasmussen, S.L., Boussaha, M., Schiøler, P., Schovsbo, N.H., Sheldon, E., Stemmerik, L. \& Thibault, N. 2013: Upper Campanian - Maastrichtian holostratigraphy of the eastern Danish Basin. Cretaceous Research 46, 232-256.

Thibault, N. 2010: Biometric analysis of the Arkhangelskiella group in the upper Campanian-Maastrichtian of the Stevns-1 borehole, Denmark: taxonomic implications and evolutionary trends. Geobios 43, 639-652.

Thibault, N., Harlou, R., Schovsbo, N., Schiøler, P., Minoletti, F., Galbrun, B., Lauridsen, B.W., Sheldon, E., Stemmerik, L. \& Surlyk, F. 2012: Upper Campanian - Maastrichtian nannofossil biostratigraphy and high resolution carbon isotope stratigraphy of the Danish Basin: towards a standard $\delta^{13} \mathrm{C}$ curve for the Boreal Realm. Cretaceous Research 33, 72-90.

Varol, O. 1998: Palaeogene. In: Bown, P.R. (ed.): Calcareous nannofossil biostratigraphy. British Micropalaeontological Society Publication Series, 200-224.

\footnotetext{
Authors'address

Geological Survey of Denmark and Greenland, ØsterVoldgade 10,DK-1350 Copenhagen K, Denmark. E-mail: es@geus.dk
} 